\title{
Remote Sensing Of The Greenland Sea
}

\section{Gudmandsen, Preben; Pedersen, Leif Toudal; Zhang, HongJiang}

\section{Published in:}

Geoscience and Remote Sensing Symposium

Publication date:

1989

Document Version

Publisher's PDF, also known as Version of record

Link back to DTU Orbit

Citation (APA):

Gudmandsen, P., Pedersen, L. T., \& Zhang, H. (1989). Remote Sensing Of The Greenland Sea. In Geoscience and Remote Sensing Symposium (Vol. 3, pp. 1545-1545). IEEE.

\section{General rights}

Copyright and moral rights for the publications made accessible in the public portal are retained by the authors and/or other copyright owners and it is a condition of accessing publications that users recognise and abide by the legal requirements associated with these rights.

- Users may download and print one copy of any publication from the public portal for the purpose of private study or research.

- You may not further distribute the material or use it for any profit-making activity or commercial gain

- You may freely distribute the URL identifying the publication in the public portal

If you believe that this document breaches copyright please contact us providing details, and we will remove access to the work immediately and investigate your claim 
Remote Sensing of the Greenland Sea

Preben Gudmandsen, Leif Toudal Pedersen, Hongjiang Zhang

Electromagnetics Institute, Remote Sensing Unit

Technical University of Denmark, DK-2800 Lyngby, Denmark

Telephone: 452 881444, Telefax: 452931634 , Telex: 37529 DTHDIA

In connection with the Greenland Sea Project a series of algorithms and analysis methods are developed for exploitation of satellite remote sensing data in the geophysical exploration of the area. Data from sensors on meteorological and earth observation sateliites are being dealt with, including the AVHRR on the TIROS series, MSS on LANDSA' $T$, and SMMR on NIMBUS 7. The satellite data are supplemented by synoptic meteorological data and data from drifting buoys, the latter on an opportunity basis.

The purpose of the exercise is to develop a comprehensive analysis system that may be used routinely to obtain parameters such as ice extent, area and concentration, ice velocity vector fields, ice classification, lead structure and direction, etc. Also, open ocean parameters such as wind field, significant waveheight, atmospheric vapour and liquid water content are of interest. Thus a series of already existing algorithms have been modified and new have been developed to suit the task of obtaining time series of information for the area. In particular, methods of presenting the different types of data with different swaths and spatial resolution have been considered with the purpose of exploiting the synergism they represent.

In the course of the development of the different parts of the analysis system data from the period February to May 1987 have been gathered and analyzed. This period is largely coinciding with the MIZEX-87 experiment which took place in the northern part of the Greenland Sea. Whereas MIZEX 87 deals with meso-scale phenomena the present work aims at data on a complementary regional scale.

In addition to presenting the analysis system and some of its elements, its performance will be considered. Interesting results from the analyses carried out will be discussed with reference to previous observations of the area. The system is designed so that a great part of it will be useful in connection with data from future satellite sensors such as the microwave sensors on ERS-1 and the likely performance of the future system will be dealt with. In particular, the sampling in time and space which will be performed by means of the synthetic aperture radar mode of the Active Microwave Instrument on ERS-1 is of concern. 